Democrat challenger, wants to "cap" some costs and was able to other day to claim the support of the American College of Physicians (not to be mistaken for the American Medical Association), which has advocated agreements to contain some medical costs - the fees charged by physicians, for example.

Developments such as these are at present unavoidable. In what was then West Germany, people in 1990 spent no less than 10 per cent of their gross national product on health care, amounting to some DM4,770 per head of population. Alarmingly, the rate of increase of spending has been running at just under 10 per cent a year - faster than the rate of economic growth in Germany's best years some time ago. The burden carried by Germany's wage-earners is substantial; health insurance alone accounts for some 13 per cent of average income. In the United States, more of the burden is shouldered by companies by way of employment-related insurance plans, and so is less conspicuous to voters, while costs are increased to an unquantifiable degree by the cost of malpractice suits (and that of the insurance physicians must buy). What will happen to these bills when the armoury of new diagnostic tests on which every other biotechnology company is working eventually reaches the market?

The difficulty is that caps and across-the-board cuts in prices are bound to be arbitrary and even inequitable. Physicians with exceptional skill or specialism will be insufficiently regarded (and others will be discouraged from following in their footsteps). And arbitrary ceilings on drug prices will penalize innovative manufacturers more than others. Are there not simpler ways of containing the costs of health care?

In both Germany and the United States, the 'market' in health care is inefficient, to say the best of it. People who are sick naturally seek a cure quickly, and do not hunt for the best bargain in the field even if they have an incentive to do so (which is often not the case). Equally, the physicians to whom they turn do not expect to have to haggle over prices in advance.

But why not require that physicians should publish to their patients and other interested parties the prices they will charge for the various services they are qualified to provide? If it were then also required that patients should pay a proportion of the cost, there would at least be a chance to see whether the market of which Bush speaks would function. And there might then be the funds left over to pay for health care for those who cannot now afford it.

\section{Rebuild research now}

The temptation to cut back on research in the current financial crisis should be resisted.

PITY poor Britain. Two years after the pound sterling was put into the European Exchange Rate Mechanism, six years after its Chancellor of the Exchequer started tracking the Deutschemark on the foreign exchanges and a dozen years after embarking on a serious effort to put its money affairs in order by cutting public spending, sterling was last week forced out again by the sheer cost of supporting its value. Italy, in similar case, also of course commands sympathy, even if its new prime minister, Mr Guiliano Amato, has hardly had a chance seriously to tackle his government's public finances. In each case, but especially in Britain, there is a danger that the consequences will include further attempts to save by spending less on science. But the British experience of the past twelve years must surely argue in the opposite direction.

As a percentage of gross domestic product, British government spending on academic and related research is now less than that of comparable European governments. Worse, as the government's own Advisory Council on Science and Technology reported in July (see Nature 358, $359 ; 1992$ ), the shortage of funds has created other problems; salaries in research compare poorly with those in the commercial field, such research spending as there is is too thinly spread and, even when universities have been able to make good the shortfall by means of contracts with industry, they are often unable to recover the full costs. All this is well known, of course, although it is valuable that one of the government's own committees now agrees. But how, the moneybags will ask, can more spending on research help a country such as Britain out of the tight corner in which it finds itself?

Although the gestation period of important and marketable industrial innovations may be long and unpredictable, the research system can yield the products which are its primary purpose - young people educated in research quickly and reliably. In the British system, a new graduate can still earn a research degree in three years or so, becoming in the process a potentially more creative member of a modern community. Whatever happens now to Europe (and Britain's place therein), this must surely be the worst possible time further to intensify the discouragement of young people from careers in research. Those tempted to act in such a way should reflect that there is at present no way of telling the degree to which an insufficient supply of such people may have contributed to the recent precipitate decline of British competitivess - the underlying cause of last week's debacle on the foreign exchanges.

With unemployment pushing steadily towards 3 million, and with pressure on the government mounting to devise some quick stimulation of the economy, perhaps by construction projects, a plea that this is not the time to provide further discouragement of research may be mistaken for special pleading.

But that is not the case. On the contrary, the immediate benefits of public spending on research should be little different from the same amount of spending on, say, construction. The difference is that the longer-term benefits will be greater. And although Britain's need to rescue its research may be more urgent than in, say, Italy and Spain (Europe's other beleaguered currency), the same truth applies there: the discouragement of research is pointless in the short run and damaging on a longer timescale. 